Article available at nttp://www.parasite-Journal.org or nttp://dx.dol.org/10.1051/parasite/1998052197

\title{
FAUNAL COMPOSITION AND BEHAVIOR OF ANOPHELINe mOSQUITOES IN the XAVÁNTE INDIAN RESERVATION of Pimentel Barbosa, Central Brazil
}

\author{
IANÉLLI R.V.*, HONÓRIO N.A.**, LIMA D.C.**, LOURENÇO-DE-OLIVEIRA R.**, \\ SANTOS R.V.***** \& COIMBRA C.E.A. Jr.*
}

\section{Summary :}

Faunal composition and behavior of anopheline mosquitoes were studied in a Xavánte Indian reservation of Central Brazil.

Altogether 558 anophelines were collected in three environments (intra, peri, and extra-domiciliary). Anopheles darlingi (30.9\%), An. triannulatus s.l. (24.6\%) and An. oswaldoi (19.7\%) were the most common species. Average capture rates were higher in the rainy season (8.03 per hour) than in the dry season (4.37 per hour). Anophelines exhibited exophilic behavior almost exclusively. It was observed that Xavánte cultural practices facilitate outdoor exposure during peak hours of mosquito activities (e. g., coming to the creek early in the morning for bathing or to draw water, fishing, etc.). The results of this study raise the question of whether or not applying to the Xavánte the more commonly recommended malaria control strategies (e. g., in-house spraying, screening windows, and impregnated bed nets) which aim at hampering human-mosquito contact inside human dwelings may be effective.

KEY WORDS : Anopheles sp., malaria, epidemiology, Amerindians, Amazonia, Brazil.

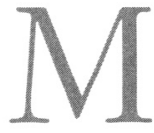
alaria is a major cause of morbidity and mortality in the Amazon Basin, where some groups, including Amerindian populations, are at special risk for infection. Malaria has taken a heavy toll among these groups, primarily after contact with the national society. However, little is known about the epidemiology of malaria among Amerindians. Aspects which are particularly poorly known include the faunal composition, ecology, and behavior of anopheline mosquitoes. These aspects may vary according

* Escola Nacional de Saúde Pública, Fundação Oswaldo Cruz, Rua Leopoldo Bulhões 1480, Rio de Janeiro, RJ 21041-210, Brazil.

** Instituto Oswaldo Cruz, Fundação Oswaldo Cruz, Av. Brasil 926, Rio de Janeiro, RJ 21045-900, Brazil.

**** Departamento de Antropologia, Museu Nacional, Quinta da Boa Vista s/n, Rio de Janeiro, RJ 20940-040, Brazil.

Correspondence: Dr. Carlos E.A. Coimbra Jr.

Fax: +55-21-2951396 - e-mail: cadernos@ensp.fiocruz.br
Résumé : COMPOSITTON FAUNISTIQUE ET COMPORTEMENT DES MOUSTIQUES ANOphÈles Chez les Indiens Xavante de la RÉSERVE DE Pimentel BARBOSA, BRÉsIL CENTRAL

La composition faunistique et le comportement des moustiques anophèles ont été étudiés dans une réserve d'Indiens Xavante du Brésil central. En tout, 558 anophèles ont été capturés, à l'intérieur, à proximité et à distance des habitations. Anopheles darlingi $(30,9 \%)$, An. triannulatus s.l. $(24,6 \%)$ et An. oswaldoi (19,7\%) sont les espèces les plus communes. Les taux moyens de capture sont plus élevés durant la saison des pluies (8,03 par heure) qu'à la saison sèche 14,37 par heure). Les anophèles ont un comportement presque exclusivement exophile. II a été observé que les habitudes culturelles des Xavante facilitent leur exposition extérieure pendant les pics d'activité des moustiques larrivée tôt le matin à la crique pour se baigner, tirer de l'eau, pêcher; etc.). Les résultats de cette étude remettent en cause l'efficacité pour les Xavante des recommandations habituelles en matière de contrôle du paludisme Ipulvérisation d'insecticide au sein de l'habitation, moustiquaires aux fenêtres, moustiquaires imprégnées autour du lit), lesquelles visent à prévenir le contact homme-moustique à l'intérieur des habitations.

MOTS CLÉS : Anopheles sp., paludisme, épidémiologie, Amérindiens, Amazonie, Brésil.

to a number of factors, including indigenous housing type, subsistence strategies, and the intensity of interaction between the Amerindian community and outsiders.

This report presents the results of a field investigation on the composition and behavior of anopheline mosquitoes in an Amerindian community in Central Brazil. It was conducted as part of a larger project aimed at better understanding the health outcomes of ongoing socio-environmental changes in Amazonian Amerindian groups.

\section{MATERIAL AND METHODS}

\section{STUDY AREA}

he study was conducted on the Xavánte reservation of Pimentel Barbosa, state of Mato

1 Grosso, Central Brazil, at the village known as 


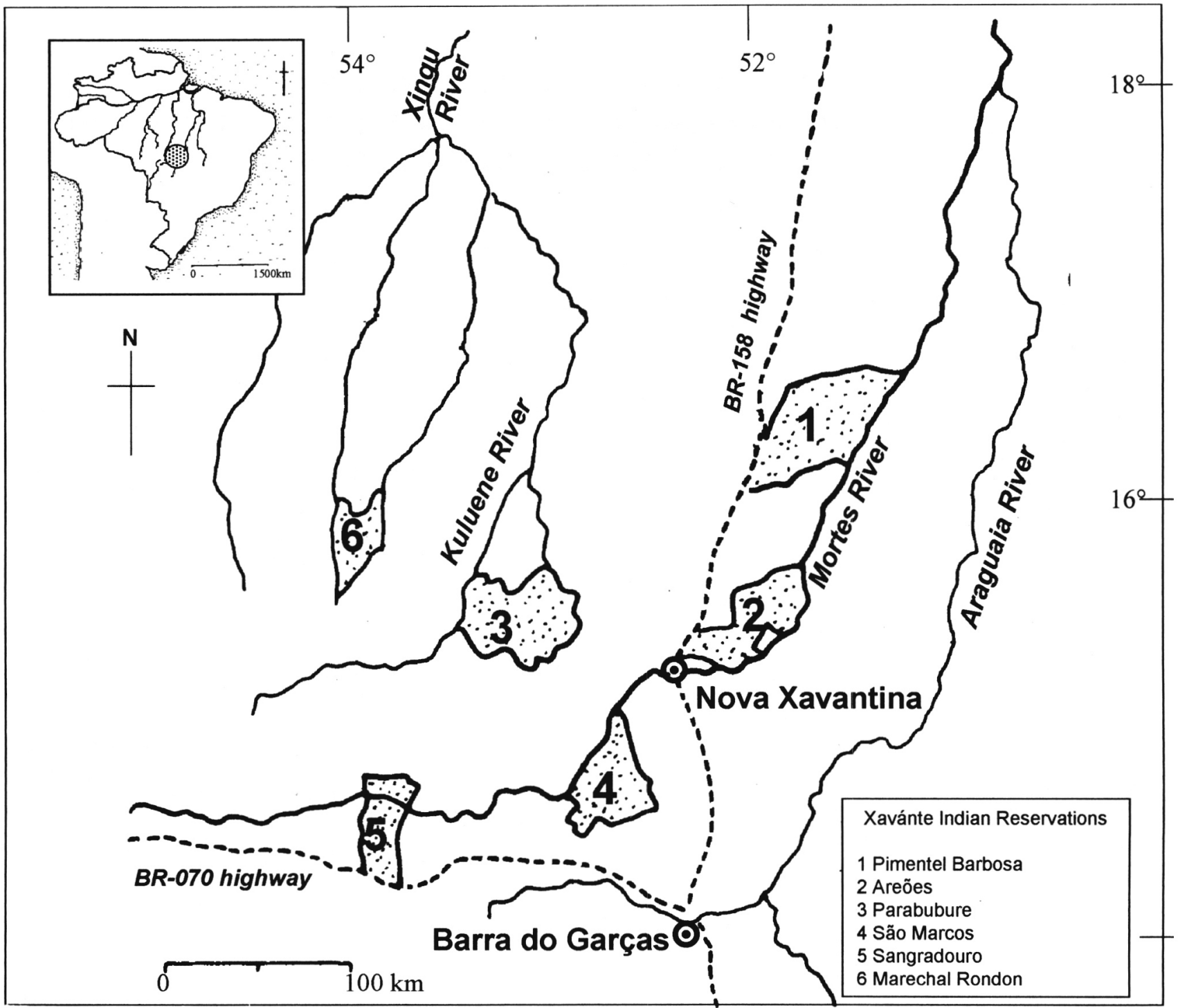

Fig. 1. - Xavánte Indians Reservations, Central Brazil.

Rio das Mortes (Fig. 1). At the time of fieldwork (19951996), the population numbered approximately 350 individuals living in 23 houses arranged in a semicircle. Most families lived in traditional beehive-shaped constructions thatched to the ground with palm leaves, with no windows and only one small entrance facing the center of the village (Fig. 2). A few Xavánte families have built houses that combine features of Xavánte and regional peasant architecture. In this case, although houses have a square base and vertical side walls, they are still fully thatched with palm leaf and do not have internal divisions nor windows. Both types of house have rather dark and humid interiors. In addition, smoke is often present, especially in those houses that have indoor cooking fires, or during winter nights when fires may be lit for warmth.

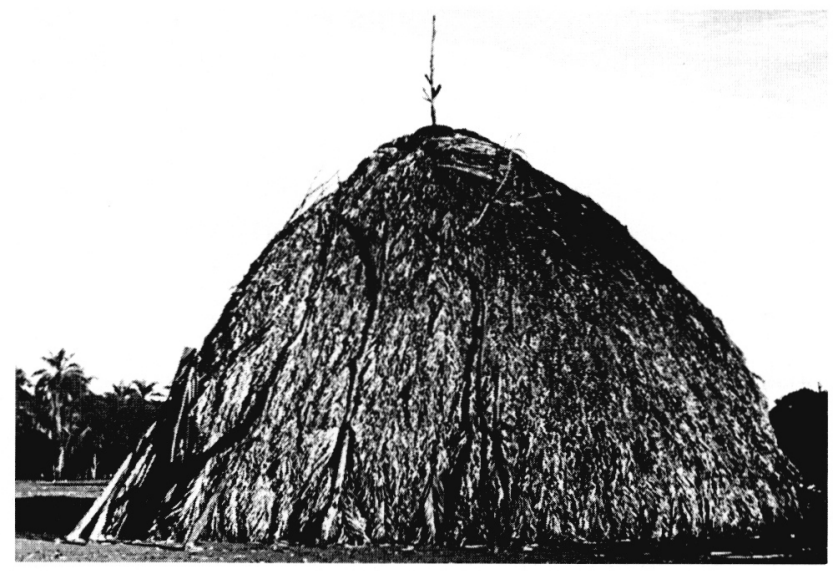

Fig. 2. - Traditional Xavánte house, Central Brazil, 1994. 
The predominant vegetation type in Xavánteland is Central Brazilian savanna or cerrado, consisting mainly of semideciduous tree-and-scrub woodland with patches of open grassland. The reservation is crisscrossed by rivers and streams of various sizes; along these watercourses a band of gallery forest includes tall trees and dense undergrowth. The Xavánte grow their subsistence crops in gardens cleared from the gallery forest.

Average monthly temperature is $24-26{ }^{\circ} \mathrm{C}$. Average annual rainfall ranges from 1,000 to 1,700 millimeters. The rains peak in December through March, whereas almost no rain falls from June to September. The terrain is fairly flat, but with rocky outcroppings which may reach as high as $500 \mathrm{~m}$ above sea level.

\section{Collection and Examination of Mosquitoes}

Mosquitoes were collected during two visits, one in the rainy season and the other at the beginning of the dry season (February 1995 and April/May 1996, respectively). Captures were conducted on human baits (the investigators) using aspirators. Daily capture sessions were simultaneously carried out at three sites: intradomiciliary (inside the Indian's houses), peri-domiciliary (in the surroundings of the houses, approximately 1-2 meters distant from the external wall, and in the center of the village), and extra-domiciliary (by the stream intensively used by villagers for bathing and drawing water, located approximately $400 \mathrm{~m}$ from the village center). Collections were made at dusk (between 5:30 pm and 7:00 pm) and early morning (between 5:30 am and 7:00 am). In addition, a single open field collection was carried out in May 1996 at a site approximately $40 \mathrm{~km}$ from the village, near an area flooded by the Mortes River. This area is frequently visited by the Xavánte for hunting and fishing. During the same month, one all-night collection $(6: 30 \mathrm{pm}-$ $6: 30 \mathrm{am}$ ) was carried out in the center of the village. The salivary glands and midgut of anophelines were dissected in search for Plasmodium infection. Parity rate was evaluated following Detinova (1962).

\section{RESULTS}

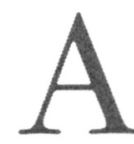

ltogether 558 anophelines were collected in the three village environments (i. e., intra, peri, and extra-domiciliary) (Table I). Most mosquitoes were collected in the extra-domiciliary (87.6\%) and in the peri-domiciliary (11.5\%) environments. The intra-domiciliary environment yielded an insignificant number of specimens $(0.9 \%)$ (Table I).

A total of 350 specimens was classified at the species level; 208 mosquitoes were damaged during transportation, therefore not permitting identification. The predominant species were Anopheles darlingi Root, 1926 (30.9 \%), An. triannulatus s.l. (Neiva \& Pinto, 1922) (24.6\%) and An. oswaldoi (Peryassu, 1922) (19.7\%). Other species included were An. rondoni (Neiva \& Pinto, 1922), An. strodei Root, 1926, An. albitarsis Lynch-Arribalzaga, 1878, An. benarrochi Gabaldon, Cova-Garcia \& Lopez, 1941, An. mediopunctatus s.l. (Theobald, 1903), An. peryassui Dyar \& Knab, 1908, An. argyritarsis Robineau-Desvoidy, 1827, An. paruus (Chagas, 1907) and Chagasia bonneae Root, 1927 (Table I).

Most mosquitoes were collected during a short highly active period which occurred in the first 15-20 minutes immediately after sunset, after which they only became active again just before sunrise. The relative lack of anopheline activity during other night hours was observed by the investigators during the all-night vigil which yielded only 6 mosquitoes. For all species, the average capture rate per hour was higher in the rainy season (8.03) than at the beginning of the dry season (4.37). The highest average capture rates were in the extra-domiciliary environment (Table I).

The single three-hour collection at the Mortes river yielded 216 specimens of Anopheles, of which 160 were identified: An. braziliensis (Chagas, 1907) (60.6\%), An. darlingi (36.3\%), An. strodei (1.3\%), An. albitarsis (0.6\%), An. rondoni (0.6\%) and An. mediopunctatus (0.6\%).

A total of 252 anophelines, collected at the village sites as well as by the Mortes River, were dissected, none of which was found to be infected with Plasmodium. The frequency of parous anopheline females was higher in the beginning of the dry season (Table II).

\section{DISCUSSION}

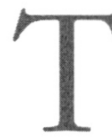
he anopheline fauna collected in the Xavánte reservation exhibited exophilic behavior almost exclusively, as the great majority of the specimens was collected by the creek near the village. Anophelines appeared to enter Xavánte houses only sporadically. A bimodal biting pattern was observed, with most specimens collected during short periods at sunset and at dawn. The investigation also revealed that An. darling $i$ is the most common species in the village environment. It is also common along the banks of the Mortes River, in an area frequently visited by the Xavánte in their hunting and fishing expeditions. Few other studies on the anopheline fauna of Amerindian reservations of Central Brazil have been carried out. Freitas-Filho (1955) undertook a general health and sanitation survey among the Pimentel Barbosa Xavánte shortly after contact. At the time of that investigation, their village was located in a site by the 


\begin{tabular}{|c|c|c|c|c|c|c|c|c|c|}
\hline \multirow[b]{3}{*}{ Species } & \multicolumn{6}{|c|}{ Sites } & \multirow{2}{*}{\multicolumn{2}{|c|}{$\begin{array}{c}\text { Total } \\
\text { (by season) }\end{array}$}} & \multirow{3}{*}{$\begin{array}{r}\text { Total } \\
\text { (global }\end{array}$} \\
\hline & \multicolumn{2}{|c|}{ intra } & \multicolumn{2}{|c|}{ peri } & \multicolumn{2}{|c|}{ extra } & & & \\
\hline & $\mathrm{R}$ & $\mathrm{D}$ & $\mathrm{R}$ & $\mathrm{D}$ & $\mathrm{R}$ & $\mathrm{D}$ & $\mathrm{R}$ & $\mathrm{D}$ & \\
\hline An. darlingi & - & $\begin{array}{c}2 \\
(0.20)\end{array}$ & - & $\begin{array}{c}5 \\
(0.20)\end{array}$ & $\begin{array}{c}38 \\
(2.24)\end{array}$ & $\begin{array}{c}63 \\
(1.97)\end{array}$ & $\begin{array}{c}38 \\
(1.15)\end{array}$ & $\begin{array}{c}70 \\
(1.04)\end{array}$ & $\begin{array}{c}108 \\
(1.08)\end{array}$ \\
\hline An. albitarsis & - & - & $\begin{array}{c}5 \\
(0.42)\end{array}$ & $\begin{array}{c}1 \\
(0.04)\end{array}$ & $\begin{array}{c}3 \\
(0.18)\end{array}$ & $\begin{array}{c}4 \\
(0.13)\end{array}$ & $\begin{array}{c}8 \\
(0.24)\end{array}$ & $\begin{array}{c}5 \\
(0.07)\end{array}$ & $\begin{array}{c}13 \\
(0.13)\end{array}$ \\
\hline An. argyritarsis & - & - & $\begin{array}{c}1 \\
(0.08)\end{array}$ & - & - & - & $\begin{array}{c}1 \\
(0.03)\end{array}$ & - & $\begin{array}{c}1 \\
(0.01)\end{array}$ \\
\hline An. benarrochi & - & - & - & $\begin{array}{c}1 \\
(0.04)\end{array}$ & - & $\begin{array}{c}1 \\
(0.03)\end{array}$ & - & $\begin{array}{c}2 \\
(0.03)\end{array}$ & $\begin{array}{c}2 \\
(0.02)\end{array}$ \\
\hline An. rondoni & - & & $\begin{array}{c}1 \\
(0.08)\end{array}$ & $\begin{array}{c}12 \\
(0.48)\end{array}$ & - & $\begin{array}{c}30 \\
(0.94)\end{array}$ & $\begin{array}{c}1 \\
(0.03)\end{array}$ & $\begin{array}{c}42 \\
(0.63)\end{array}$ & $\begin{array}{c}43 \\
(0.43)\end{array}$ \\
\hline An. mediopunctatus & - & - & - & - & $\begin{array}{c}2 \\
(0.12)\end{array}$ & - & $\begin{array}{c}2 \\
(0.06)\end{array}$ & - & $\begin{array}{c}2 \\
(0.02)\end{array}$ \\
\hline An. oswaldo $i$ & $\begin{array}{c}1 \\
(0.25)\end{array}$ & $\begin{array}{c}1 \\
(0.10)\end{array}$ & $\begin{array}{c}15 \\
(1.25)\end{array}$ & - & $\begin{array}{c}50 \\
(2.94)\end{array}$ & $\begin{array}{c}2 \\
(0.06)\end{array}$ & $\begin{array}{c}66 \\
(2.00)\end{array}$ & $\begin{array}{c}3 \\
(0.04)\end{array}$ & $\begin{array}{c}69 \\
(0.69)\end{array}$ \\
\hline An. parvus & - & - & - & - & $\begin{array}{c}1 \\
(0.06)\end{array}$ & - & $\begin{array}{c}1 \\
(0.03)\end{array}$ & - & $\begin{array}{c}1 \\
(0.01)\end{array}$ \\
\hline An. peryassui & - & - & - & $\begin{array}{c}2 \\
(0.08)\end{array}$ & - & - & - & $\begin{array}{c}2 \\
(0.03)\end{array}$ & $\begin{array}{c}2 \\
(0.02)\end{array}$ \\
\hline An. strodei & - & - & - & $\begin{array}{c}3 \\
(0.12)\end{array}$ & - & $\begin{array}{c}12 \\
(0.38)\end{array}$ & - & $\begin{array}{c}15 \\
(0.22)\end{array}$ & $\begin{array}{c}15 \\
(0.15)\end{array}$ \\
\hline An. triannulatus & - & - & $\begin{array}{c}4 \\
(0.33)\end{array}$ & - & $\begin{array}{c}77 \\
(4.53)\end{array}$ & $\begin{array}{c}5 \\
(0.16)\end{array}$ & $\begin{array}{c}81 \\
(2.45)\end{array}$ & $\begin{array}{c}5 \\
(0.07)\end{array}$ & $\begin{array}{c}86 \\
(0.86)\end{array}$ \\
\hline Anopheles sp. & $\begin{array}{c}1 \\
(0.25)\end{array}$ & - & $\begin{array}{c}6 \\
(0.50)\end{array}$ & $\begin{array}{c}8 \\
(0.32)\end{array}$ & $\begin{array}{c}60 \\
(3.53)\end{array}$ & $\begin{array}{c}133 \\
(4.16)\end{array}$ & $\begin{array}{c}67 \\
(2.03)\end{array}$ & $\begin{array}{c}141 \\
(2.10)\end{array}$ & $\begin{array}{c}208 \\
(2.08)\end{array}$ \\
\hline Chagasia bonneae & - & - & - & - & - & $\begin{array}{c}8 \\
(0.25)\end{array}$ & - & $\begin{array}{c}8 \\
(0.12)\end{array}$ & $\begin{array}{c}8 \\
(0.08)\end{array}$ \\
\hline Total & $\begin{array}{c}2 \\
(0.50)\end{array}$ & $\begin{array}{c}3 \\
(0.30)\end{array}$ & $\begin{array}{c}32 \\
(2.67)\end{array}$ & $\begin{array}{c}32 \\
(1.28)\end{array}$ & $\begin{array}{c}231 \\
(13.6)\end{array}$ & $\begin{array}{c}258 \\
(8.06)\end{array}$ & $\begin{array}{c}265 \\
(8.03)\end{array}$ & $\begin{array}{l}293 \\
(4.37)\end{array}$ & $\begin{array}{c}558 \\
(5.58)\end{array}$ \\
\hline Hour/person & 4 & 10 & 12 & 25 & 17 & 32 & 33 & 67 & 100 \\
\hline
\end{tabular}

Table I. - Absolute frequencies and bite rate of anopheline mosquitoes captured at the Pimentel Barbosa Indian Reservation, Central Brazil, according to site of collection (intra-domiciliary, peri-domiciliary and extra-domiciliary) and season ( $\mathrm{R}=$ rainy and $\mathrm{D}=$ dry season).

\begin{tabular}{|c|c|c|c|c|}
\hline & \multicolumn{2}{|c|}{ Rainy season } & \multicolumn{2}{|c|}{ Dry season } \\
\hline & $n$ & $\begin{array}{c}\% \\
\text { parous }\end{array}$ & $n$ & $\begin{array}{c}\% \\
\text { parous }\end{array}$ \\
\hline An. darlingi & 17 & 58.0 & 40 & 71.8 \\
\hline An. albitarsis & 6 & 83.0 & 2 & 100.0 \\
\hline An. argyritarsis & 1 & 0 & - & - \\
\hline An. brasiliensis & - & - & 18 & 83.3 \\
\hline An. rondoni & 1 & 100.0 & 16 & 1000 \\
\hline An. mediopunctatus & 2 & 100.0 & - & - \\
\hline An. oswaldo $i$ & 58 & 62.1 & 5 & 80.0 \\
\hline An. parvus & 1 & 100.0 & - & - \\
\hline An. peryassui & - & - & 2 & 50.0 \\
\hline An. strodei & - & - & 4 & 75.0 \\
\hline An. triannulatus & 34 & 67.6 & 1 & 100.0 \\
\hline Anopheles sp. & 30 & 66.6 & 14 & 79.2 \\
\hline Total & 150 & 65.1 & 102 & 79.2 \\
\hline
\end{tabular}

Table II. - Frequencies of dissected anophelines and percentage of parous females collected at the Pimentel Barbosa Indian Reservation, Central Brazil, according to season.
Mortes River. An. darlingi was found to be the predominant species ( $65 \%$ of the total anophelines captured). A more recent investigation by Lourenço-de-Oliveira (1989) in the Xingu National Park, which is located north of the Xavante area, also identified $A n$. darlingi as the most common species $(90 \%$ of the total) and clearly pointed to its predominantly exophilic behavior ( $87 \%$ were collected by the rivers). Earlier studies carried out in Central Brazil also pointed out to the exophilic propensities of An. darling $i$ in the region (Rachou, 1958).

The recurrent observation in this study of $A n$. darlingi as exophilic may stem, at least in part, from the peculiarities of Amerindian house architecture in Central Brazil. The closed and dark interior of these dwellings may hamper the adaptation of local Anopheles populations with endophilic/endophagic propensities. The constant in-house fires for cooking and/or heating may also contribute to the apparent insect-repellent character of the traditional Indian house. This feature 
has been demonstrated to discourage house infestation by triatomine bugs, the vectors of Chagas' disease (Coimbra, 1989; Coimbra et al., 1992). However, one can not rule out the possibility that the predominantly exophilic behavior of anophelines on Amerindian reservations might be associated with changes in mosquito behavior due to house spraying with residual insecticides such as DDT. Employees of the Brazilian National Indian Foundation confirmed that house spraying was practiced in Xavánte villages as early as the late 1940s, particularly in those located along the Mortes River. Other studies carried out in Amazonia have also suggested an association between house spraying and possible change in anopheline behavior (Camargo et al., 1994; Lourenço-de-Oliveira et al., 1989; Rebêlo et al., 1997).

$A n$. darling $i$ as well as other potential malaria vectors, such as An. oswaldoi, presented a marked degree of exophily in the community. Certain Xavánte cultural practices facilitate outdoor exposure to anopheline attacks. Xavánte women and children often start their daily round by going to the village stream around five in the morning for bathing and to draw water. On their way to the gardens, Xavánte couples also take time for an early swim in the creek. Xavánte children and adults also go to the stream at the end of the day and often stay until the sun sets. By the water, the Xavánte wear little or no clothing. Considering that $93.5 \%$ of all $A n$. darling $i$ were captured by the banks of the village stream, one might conclude that the Xavánte pattern of water use exposes individuals of both sexes and of all ages to numerous mosquito bites. It should be noted that this pattern of human/mosquito contact in Amerindian populations of Central Brazil was also observed among the Kayapó-Mentuktíre in the Xingu National Park, approximately $300 \mathrm{~km}$ north of the Xavánte reservation (Lourenço-de-Oliveira, 1989).

The results of this investigation provide useful information for critical evaluation of malaria control programs in Amerindian populations. Recent sero-epidemiological surveys for malaria carried out among the Pimentel Barbosa Xavánte have revealed a high frequency of positivity to $P$. falciparum and $P$. vivax antibodies (Coimbra et al., 1995; Ianelli, 1997). The exophilic character of $A n$. darling $i$ in the Xavánte area, in conjunction with the group's water use pattern, raises doubts as to the effectiveness of applying the more commonly recommended malaria control strategies, e. g., biannual in-house spraying with residual insecticides, screening windows, and using impregnated bed nets. All such measures aim at hampering the possible human-mosquito contact inside human dwellings, taking for granted that anophelines will exhibit endophilic and endophagic behaviors. On the one hand, the Xavánte seem to have managed to develop a rela- tively " mosquito proof " house, thus not requiring bed nets or screens (their houses actually do not have windows to be screened). On the other hand, their pattern of water use, which brings them to the banks of the village stream at the time when the mosquitoes are most active, makes them vulnerable to attack by exophilic mosquitoes. Alternative malaria control measures should be developed in order to better respond to the particular needs of Amerindian populations living in areas endemic for malaria.

\section{ACKNOWLEDGEMENTS}

T o Nancy M. Flowers (Hunter College/CUNY, New York) for her critical comments on the manuscript. Financial support was provided by the Small Grants Program of TDR/UNDP/World Bank/WHO (SG-P94.214) through the Laboratorio de Ciencias Sociales of the Universidad Central de Venezuela, the MacArthur Foundation, and Fundação Oswaldo Cruz (Papes A-1997). The Brazilian National Indian Foundation (FUNAI) granted authorization for field work and provided logistic support through its regional office in Nova Xavantina. The authors are also indebted to the Xavánte for their hospitality and support.

\section{REFERENCES}

Camargo L.M., Ferreira M.U., Krieger H., Camargo E.P. \& Silva L.P. Unstable hypoendemic malaria Rondonia (Western Amazon region, Brazil): epidemic outbreaks and work-associated incidence in an agro-industrial rural settlement. American Journal of Tropical Medicine and Hygiene, 1994, 51, 16-25.

CoImBra C.E.A. Jr. Human settlements, demographic pattern, and epidemiology in lowland Amazonia: the case of Chagas's disease. American Anthropologist, 1989, 90, 82-97.

Coimbra C.E.A. Jr., Borges M.M., Flowers N.M., Santos R.V. \& Piazza R. Sero-epidemiological survey for Chagas' disease among the Xavánte Indians of Central Brazil. Annals of Tropical Medicine and Parasitology, 1992, 86, $567-568$

Coimbra C.E.A., Ferreira-Da-Cruz M.F., Daniel-Ribeiro C.T., SANTOS R.V. \& PASso R.M. Sero-epidemiology of malaria in the Xavánte and Tupí-Mondé Indians from Mato Grosso and Rondônia, Brazil. Revista da Sociedade Brasileira de Medicina Tropical, 1995, 28 (Suppl. 1), 155.

Detinova T.S. Age-Grouping Methods in Diptera of Medical Importance. WHO Monograph Series No. 47, World Health Organization, Geneva, 1962.

Freitas-Filho S.A. Inquérito médico-sanitário entre os índios Xavante. In: Relatório de Atividades do Serviço de Proteção aos Índios Durante o Ano de 1954. Simões M.F. (ed.), Serviço de Proteção aos Índios, Rio de Janeiro, 1955, $145-172$. 
Ianelu R.V. Perfil Epidemiológico da Malária em uma População Indigena do Brasil Central: Os Xavánte de Pimentel Barbosa. M.P.H. Thesis, Escola Nacional de Saúde Pública, Rio de Janeiro, 1997.

LourençO-DE-Oliveira R. Some observations on the mosquitoes of Indian settlements in Xingu National Park, Mato Grosso State, Brazil, with emphasis on malaria vectors. Revista Brasileira de Biologia, 1989, 49, 393-397.

Lourenço-De-Oliveira R., Guimarães A.E.G., Arlé M., Silva T.F.S., Castro M.G., Motta M.A. \& Deane L.M. Anopheline species, some of their habits and relation to malaria in endemic areas of Rondonia state, Amazon region of Brazil. Memórias do Instituto Oswaldo Cruz, 1989, 84, 501-514.

Rachou R.G. Anofelinos do Brasil: Comportamento das espécies vetoras de malária. Revista Brasileira de Malariologia e Doenças Tropicais, 1958, 10, 145-181.

Rebelo J.M.M., Silva A.R., Ferreira L.A. \& Vieira J.A. Anopheles (Culicidae, Anophelinae) e a malária em Buriticupu-Santa Luzia, Pré-Amazônia Maranhense. Revista da Sociedade Brasileira de Medicina Tropical, 1997, 30, 107-111.

Reçu le 24 octobre 1997 Accepté le 20 février 1998 